\title{
A histochemical study of simple laryngeal polyps
}

\author{
GP EDLIN*
}

From the Department of Histopathology, Ninewells (Teaching) Hospital and Medical School, Dundee, UK

SUMMARY Benign laryngeal polyps and normal larynxes have been studied by histochemical and other staining methods. These show that the polyps contain much free hyaluronic acid and 6-chondroitin sulphate. Their mode of production may be the mechanical separation of these compounds from collagen fibres by vibration. An alcian-elastic stain may be a helpful diagnostic method.

Laryngeal polyps (singer's nodes) are familiar to laryngologists and surgical histopathologists, but their pathogenesis has not been agreed. The histological features of laryngeal polyps have similarities with those of myxoedema of the larynx, and this study sets out to determine whether there are histochemical changes in laryngeal polyps and myxoedema of the larynx that could be diagnostically useful or throw light upon their pathogenesis.

Ogawa ${ }^{1}$ has demonstrated alcianophilia in laryngeal polyps that was abolished by pretreatment with hyaluronidase and chondroitinase, but Zbořil and Nožička ${ }^{2}$ were unable to show differences between the normal larynx and laryngeal polyps by the periodic acid-Schiff (PAS) technique. The groundsubstance of the myxoedematous larynx has been found to contain acid mucopolysaccharides ${ }^{3}$ which were also present in the true vocal cord of the hypothyroid rat. ${ }^{4}$

It has been shown that different types of acid mucopolysaccharides show alcianophilia at varying $\mathrm{pH}$ or at critical electrolyte concentrations and compete in characteristic ways with other dyes. ${ }^{5-7}$ These techniques have been used to compare laryngeal polyps and the myxoedematous larynx with the normal vocal cord.

\section{Material and methods}

Twenty-five laryngeal polyps were examined. Control material from 16 larynxes showing no morphological abnormality was obtained by taking transverse blocks across the vocal cords in a similar manner to that of Browning et al. ${ }^{8} \mathrm{~A}$ biopsy from a patient with myxoedema of autoimmune aetiology

*Present address: University Hospital of Wales, Cardiff

Received for publication 3 January 1980 who presented with hoarseness of voice was also available.

All the polyps had been diagnosed independently as showing characteristic histological features of the lesion, including vascular proliferation, fibrosis, or a myxoid appearance of the underlying stroma.

The specimens were all fixed for 24 hours in Lillie's buffered formalin, post-fixed for 16 hours in formol-corrosive, dehydrated in alcohol, cleared in toluene, and embedded in paraffin wax. Sections were cut at $6 \mu \mathrm{m}$. Sections were stained by the following methods: ${ }^{9}$ alcian blue at $\mathrm{pH} 0 \cdot 2,1 \cdot 0$, and 2.5 ; alcian blue at $\mathrm{pH} 2.5$ after treatment with hyaluronidase; alcian blue/aldehyde fuchsin and alcian blue/PAS at $\mathrm{pH} 2 \cdot 5$, and Weigert's elastic stain. Additionally, some sections were stained with Congo red for amyloid and by the martius scarlet blue (MSB) technique for fibrin.

Results (see table)

The normal laryngeal connective tissue gave negative or inconstant weak staining with alcian blue at $\mathrm{pH} 0.2$ but very little alcianophilia at $\mathrm{pH} 1.0$ and $2 \cdot 5$. A band of elastic tissue parallel to the surface

Table Comparison of staining methods on normal tissue and laryngeal polyps

\begin{tabular}{|c|c|c|c|c|c|c|}
\hline \multirow{2}{*}{$\begin{array}{l}\text { Staining method } \\
\begin{array}{l}\text { Degree of } \\
\text { alcianophilia }\end{array}\end{array}$} & \multicolumn{3}{|c|}{$\begin{array}{l}\text { Normal tissue } \\
16 \text { studied }\end{array}$} & \multicolumn{3}{|c|}{$\begin{array}{l}\text { Laryngeal polyps } \\
25 \text { studied }\end{array}$} \\
\hline & ++ & + & - & ++ & $\therefore$ & - \\
\hline Alcian blue, pH 0.2 & - & 9 & 7 & 22 & 3 & - \\
\hline Alcian blue, pH 1.0 & - & 2 & 14 & 2 & 23 & - \\
\hline Alcian blue, $\mathrm{pH} 2.5$ & - & 3 & 13 & 21 & 4 & - \\
\hline $\begin{array}{l}\text { Alcian blue/PAS } \\
\text { Alcian blue/aldehyde } \\
\text { fuchsin }\end{array}$ & \multicolumn{3}{|c|}{$\begin{array}{l}16 \text { PAS + ve } \\
16 \text { fuchsin + ve }\end{array}$} & \multicolumn{3}{|c|}{$\begin{array}{l}\text { PAS - ve } 25 \\
\text { Variable results }\end{array}$} \\
\hline Weigert's elastica & \multicolumn{3}{|c|}{16 positive } & \multicolumn{3}{|c|}{ Negative 25} \\
\hline
\end{tabular}


epithelium was fuchsinophil with alcian blue/ aldehyde fuchsin and PAS positive with alcian blue/PAS.

By contrast, the stroma of the singer's nodes showed strong and consistent alcianophilia at pH 0.2 and 2.5 with positive but less strong staining at $\mathrm{pH} 1.0$; all these reactions were abolished by pretreatment with hyaluronidase. Elastica was virtually absent when stained by the Weigert technique, and there was partial loss of fuchsinophilia with alcian blue/aldehyde fuchsin. The myxoedema case showed the presence of elastic tissue but the stromal connective tissue stained as a singer's node. No fibrin or amyloid was demonstrated by the MSB or Congo red methods.

\section{Discussion}

Acid mucopolysaccharides combine with alcian blue at different $\mathrm{pH}$ levels according to their composition. At low pH sulphated radicals become ionised and react, while unsulphated radicals do not. At pH 2.5 most acid mucopolysaccharides will stain with alcian blue. Those radicals which are finely attached to collagen will not react under any conditions, and large molecules present fewer binding sites for a given molecular weight than small ones. The staining reactions of the collagen of the normal larynx suggest that there is a little sulphated material but no unsulphated mucopolysaccharides. In the singer's nodes the mucopolysaccharides appear to be of smaller molecular size, to be less avidly linked to collagen, and to consist of highly sulphated and unsulphated compounds. These findings would be consistent with the presence of chondroitin sulphates and hyaluronic acid in the singer's nodes while the normal larynx contains a little 6-chondroitin sulphate but is free from hyaluronic acid, confirming Ogawa's work using less specific chrondroitinases. In the myxoedematous larynx alcianophilia at varying $\mathrm{pH}$ has been demon- strated, and although Bicknell ${ }^{3}$ thought that this was diagnostic, the present study has shown that similar staining reactions are found in singer's nodes, and an elastic stain would be helpful in distinguishing these changes.

In incomplete ultrastructural studies Busuttil10 has suggested that the mechanical effects of vibration broke off small fragments from collagen fibres in singer's nodes. It is postulated that the presence of hyaluronic acid and 6-chondroitin sulphate is due to these compounds being freed from collagen by high-frequency vibration.

\section{References}

${ }^{1}$ Ogawa H. Histochemical studies of laryngeal polyp. $J$ Otolaryngol Japan 1972;75:682-91.

${ }^{2}$ Zbořil M, Nožička Z. Histological and clinical diagnosis of the singer's nodes and of the polyps of the vocal cords. (Czech) Cesk Otolaryngol 1971;20:56-9.

${ }^{3}$ Bicknell PG. Mild hypothyroidism and its effects on the larynx. J Laryn Otol 1973;87:123-7.

4 Ritter FN. The effects of hypothyroidism upon the ear, nose and throat. J Laryngoscope 1967;77:1427-79.

${ }^{5}$ Spicer SS, Meyer DB. Histochemical differentiation of acid mucopolysaccharides by means of combined aldehyde fuchsin-alcian blue staining. Techn Bull Regist of Med Techn 1960;30:53-60.

${ }^{6}$ Spicer SS, Wollman SH, Warren L. Histochemical demonstration of sialomucin in transplantable thyroid carcinoma. Am J Pathol 1960;37:599-611.

${ }^{7}$ Spicer SS. The use of various cationic reagents in histochemical differentiation of mucopolysaccharides. Am J Clin Pathol 1961;36:393-407.

${ }^{8}$ Browning GG, Busuttil A, McLay A. An improved method of reporting laryngectomy specimens. $J$ Pathol 1976;119:101-3.

- Cook HC. Manual of Histological Demonstration Techniques. London: Butterworths, 1974:212.

${ }^{10}$ Busuttil A. Personal communication, 1976.

Requests for reprints to: Dr GP Edlin, Pathology Department, Royal Hampshire County Hospital, Winchester, UK. 